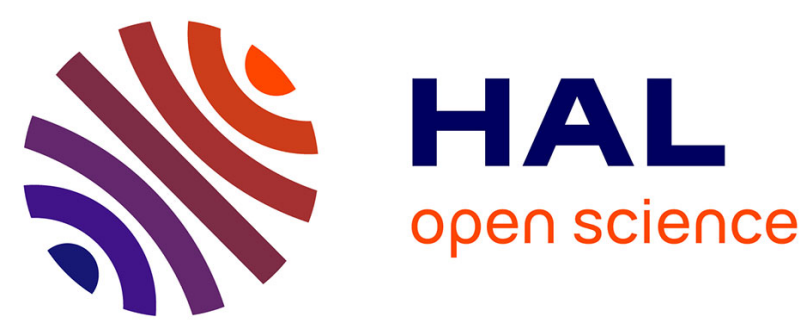

\title{
Antibody-Functionalized Magnetic Polymersomes: In vivo Targeting and Imaging of Bone Metastases using High Resolution MRI
}

Line Pourtau, Hugo de Oliveira, Julie Thevenot, Yali Wan, Alain R. Brisson, Olivier Sandre, Sylvain Miraux, Eric Thiaudière, Sébastien Lecommandoux

\section{To cite this version:}

Line Pourtau, Hugo de Oliveira, Julie Thevenot, Yali Wan, Alain R. Brisson, et al.. AntibodyFunctionalized Magnetic Polymersomes: In vivo Targeting and Imaging of Bone Metastases using High Resolution MRI. Advanced Healthcare Materials, 2013, 2 (11), pp.1420-1424. 10.1002/adhm.201300061 . hal-00926530

\section{HAL Id: hal-00926530 https://hal.science/hal-00926530}

Submitted on 3 Nov 2018

HAL is a multi-disciplinary open access archive for the deposit and dissemination of scientific research documents, whether they are published or not. The documents may come from teaching and research institutions in France or abroad, or from public or private research centers.
L'archive ouverte pluridisciplinaire HAL, est destinée au dépôt et à la diffusion de documents scientifiques de niveau recherche, publiés ou non, émanant des établissements d'enseignement et de recherche français ou étrangers, des laboratoires publics ou privés. 
DOI: $10.1002 / \mathrm{adhm} .201300061$

\section{Antibody-functionalized magnetic polymersomes: in vivo targeting and imaging of bone metastases using high resolution MRI}

By Line Pourtau $^{+}$, Hugo Oliveira ${ }^{+}$, Julie Thevenot, Yali Wan, Alain Brisson, Olivier Sandre, Sylvain Miraux, Eric Thiaudière* and Sébastien Lecommandoux*

Multifunctional polymersomes loaded with maghemite nanoparticles and grafted with an antibody, directed against human endothelial receptor 2, are developed as novel MRI contrast agents for bone metastasis imaging. Upon administration, in mice bearing orthotopic metastatic breast cancer, MR images show targeting and enhanced retention of antibodylabeled polymersomes at the tumor site.

Keywords: Magnetic Resonance Imaging, Polymersome, Targeting, Bone Tumor

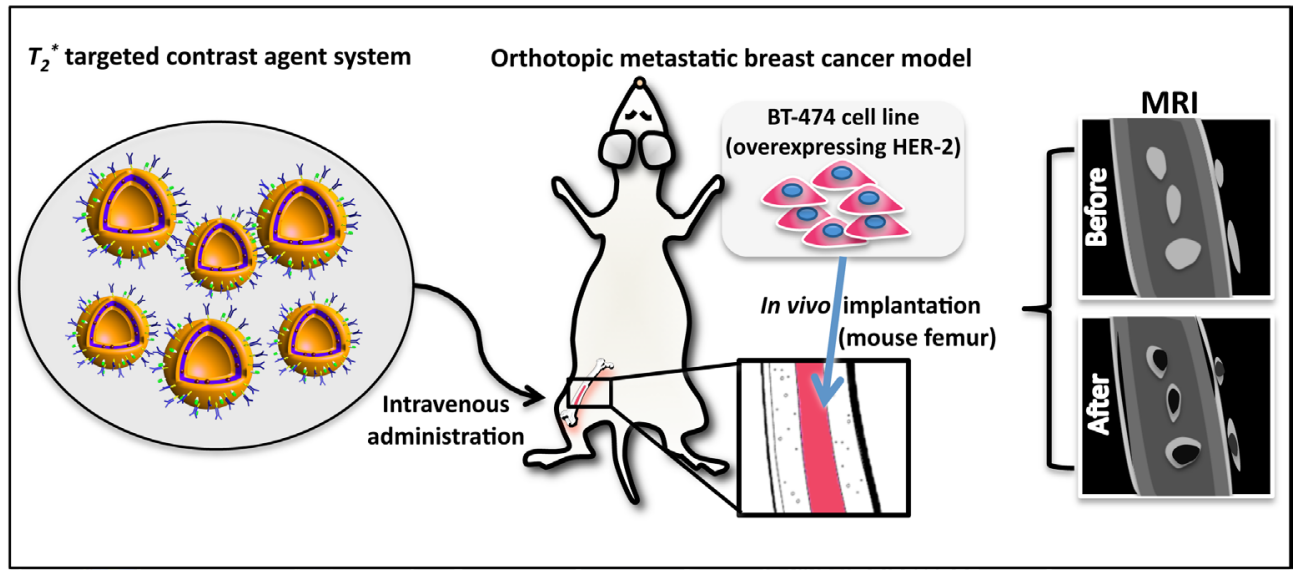


DOI: $10.1002 / \mathrm{adhm} .201300061$

\section{Antibody-functionalized magnetic polymersomes: in vivo targeting and imaging of bone metastases using high resolution MRI}

By Line Pourtau $^{+}$, Hugo Oliveira ${ }^{+}$, Julie Thevenot, Yali Wan, Alain Brisson, Olivier Sandre, Sylvain Miraux, Eric Thiaudière* and Sébastien Lecommandoux*

$\left[{ }^{+}\right]$These authors contributed equally to this work.

[*] Prof. Sébastien Lecommandoux Author-Nine Corresponding-Author, Dr. Julie Thevenot Author-Three, Dr. Hugo Oliveira Author-Two, Dr. Olivier Sandre Author-Six Université de Bordeaux, LCPO, UMR 5629, F-33600 Pessac, France.

CNRS, LCPO, UMR 5629, F-33600 Pessac, France.

E-mail: (lecommandoux@enscbp.fr)

[*] Prof. Eric Thiaudière Author-Eight Corresponding-Author, Dr. Sylvain Miraux Author-Seven, Dr Line Pourtau First Author

Centre de Résonance Magnétique des Systèmes Biologiques, UMR 5536, Université Bordeaux Segalen, CNRS, France.

E-mail: (eric.thiaudiere@,rmsb.u-bordeaux2.fr)

Prof. Alain Brisson Author-Five, Yali Wan Author-Four

Université de Bordeaux, CNRS, Chimie et Biologie des Membranes et des Nanoobjets (UMR5248), 33600 Pessac, France

Keywords: Magnetic Resonance Imaging, Polymersome, Targeting, Bone Tumor 
Breast cancer is the most prevalent cancer and second leading cause of cancer mortality in women. ${ }^{[1]}$ In nearly $50 \%$ of primary cancers, and $80 \%$ of recurring metastases, this type of cancer preferentially metastasizes to the skeleton, e.g. femur, pelvis, vertebrae and skull ${ }^{[2]}$, leading to poor vital prognosis. ${ }^{[3]}$. Due to their body location (profound tissue surrounded by a mineralized bone matrix) and the heterogeneity of pathological tissue, the use of new tools, allowing specific detection of these malignant cells, may result in better treatment outcome and patient survival. High-performance imaging, providing spatial resolution in three dimensions, is required for the detection of small-sized tumors (such as early metastatic stages). In this context, magnetic resonance imaging (MRI) is a good candidate for noninvasive characterization of tumor development in vivo. Widely implemented in clinical practice, MRI provides a sensitive method for the detection of bone marrow metastases. ${ }^{[4]}$ Tumor detection is usually carried out using the natural or gadolinium-enhanced contrast between healthy tissue and tumor tissue, but specifically targeted contrast agents can ensure precise tumor delineation and allow a more accurate diagnostic.

During the past two decades, magnetic nanoparticles and particularly ultrasmall superparamagnetic iron oxide nanoparticles (USPIOs) and clusters of the later (generally assembled using organic material and designated as superparamagnetic iron oxides, SPIOs) ${ }^{[5]}$ have been widely investigated as MRI contrast agents owing to their unique characteristics: efficient contrast effects (as negative $\left(T_{2}\right)$ contrast agents), biocompatibility, and possible surface functionalization. ${ }^{[5,6]}$ Recent work has indeed demonstrated the utility of targeting iron oxide particles towards the development of pathology-specific MRI contrast agents. ${ }^{[7,8,9 \text {, }}$ 10]

On the other hand, polymersomes, vesicular structures generated by self-assembly of amphiphilic copolymers, are promising drug carriers that can accommodate both hydrophobic and hydrophilic cargo within their membrane and aqueous core, respectively. ${ }^{[1]}$ Recently, several authors have shown that high amounts of USPIOs could be incorporated within these 
structures with a good control over their morphology and size and, at the same time, superior transverse relaxometric properties (high $r_{2}$ values). ${ }^{[12]}$ Our group previously developed such hybrid polymersomes where the embedded USPIOs acted as both MRI contrast agents (with $r_{2}$ up to $182 \mathrm{~s}^{-1} \cdot \mathrm{mM}_{\mathrm{Fe}}{ }^{-1}$ ) and actuators for magnetic field induced drug release (magnetochemotherapy). ${ }^{[13]}$ Another interesting development of polymersomes in the recent years is their functionalization with targeting molecules (protein, peptide or small molecule). Indeed, targeted polymersomes have been successfully implemented for vascular targeting and receptor-mediated endocytosis ${ }^{[14]}$, leading to improved drug efficiency, especially with antibodies as ligand $^{[15]}$.

Here, by means of polymersome surface functionalization using cell specific targeting ligands (antibodies), we demonstrate hybrid polymersomes application as $T_{2}{ }^{*}$ MRI contrast agents for specific targeting of a breast cancer bone metastases model. The overexpression of the membrane tyrosine kinase Human Epidermal Growth Factor Receptor-2 (HER2), found in approximately $20 \%$ of breast cancers ${ }^{[16]}$, is associated with a poor prognosis, making this receptor a potential target for guided therapy. Indeed, several examples of successful HER2 targeting have been recently described. ${ }^{[7,8,17,18][18]}$ Hence, trastuzumab, the first monoclonal humanized antibody targeting HER2, approved by FDA in 1998, and currently applied in the clinical field, ${ }^{[19]}$ was used as ligand to target breast cancer cells in a bone metastasis model. Polymersomes were prepared from a blend of amphiphilic block copolymers: poly(trimethylene carbonate)- $b$-poly(glutamic acid), the same copolymer end-capped with either a maleimide group or fluorescein, and hydrophobically coated USPIOs $(30 \mathrm{wt} \%$ to polymer). After nanoprecipitation in buffer, maleimide-bearing polymersomes were reacted with thiol-derivatized trastuzumab to obtain the targeted multifunctional polymer vesicles (Figure 1A, experimental procedures are detailed in Supporting Information).

These multifunctional polymersomes were further tested in a clinically relevant model. A majority of studies focused in large subcutaneous xenograft cancer models ${ }^{[7,8,18]}$, presenting 
poor relevance in a metastasis detection scenario. Indeed, in some cases, the tumor volume reached $1 \mathrm{~cm}^{3}$, representing a significant percentage of the mice body weight. The size of the tumors can influence tumor vascularization and dramatically change its microenvironment, with a drastic impact on the contrast agent overall performances. ${ }^{[20]}$ Recently, a more realistic animal model was presented by Kievit et al. ${ }^{[21]}$ : transgenic mice with intact immune system were used, developing tumors in a natural manner, with metastases appearing in lungs, liver and bone. Unfortunately, due to their small size, bone metastases were not detected by MRI in this study. Here, focusing on a diagnostic clinical scenario, we propose an animal model bearing small tumors $(12-15 \mu 1)$, mimicking a relevant metastasis environment. Spontaneous bone metastases, arising from primary breast tumor, are uncommon and this has prompted the wide use of bone tumor models based on local or systemic injection of tumor cells. One of the main disadvantages of the systemic injection resides on the lack of control of the tumor final localization and pathogenesis. ${ }^{[22]}$ In that sense, we developed a bone cancer model by injecting BT-474 cells (HER2-positive cell line) directly in the femoral bone of NOD/SCID mice. (Figure 1B, experimental procedures are detailed in Supporting Information).

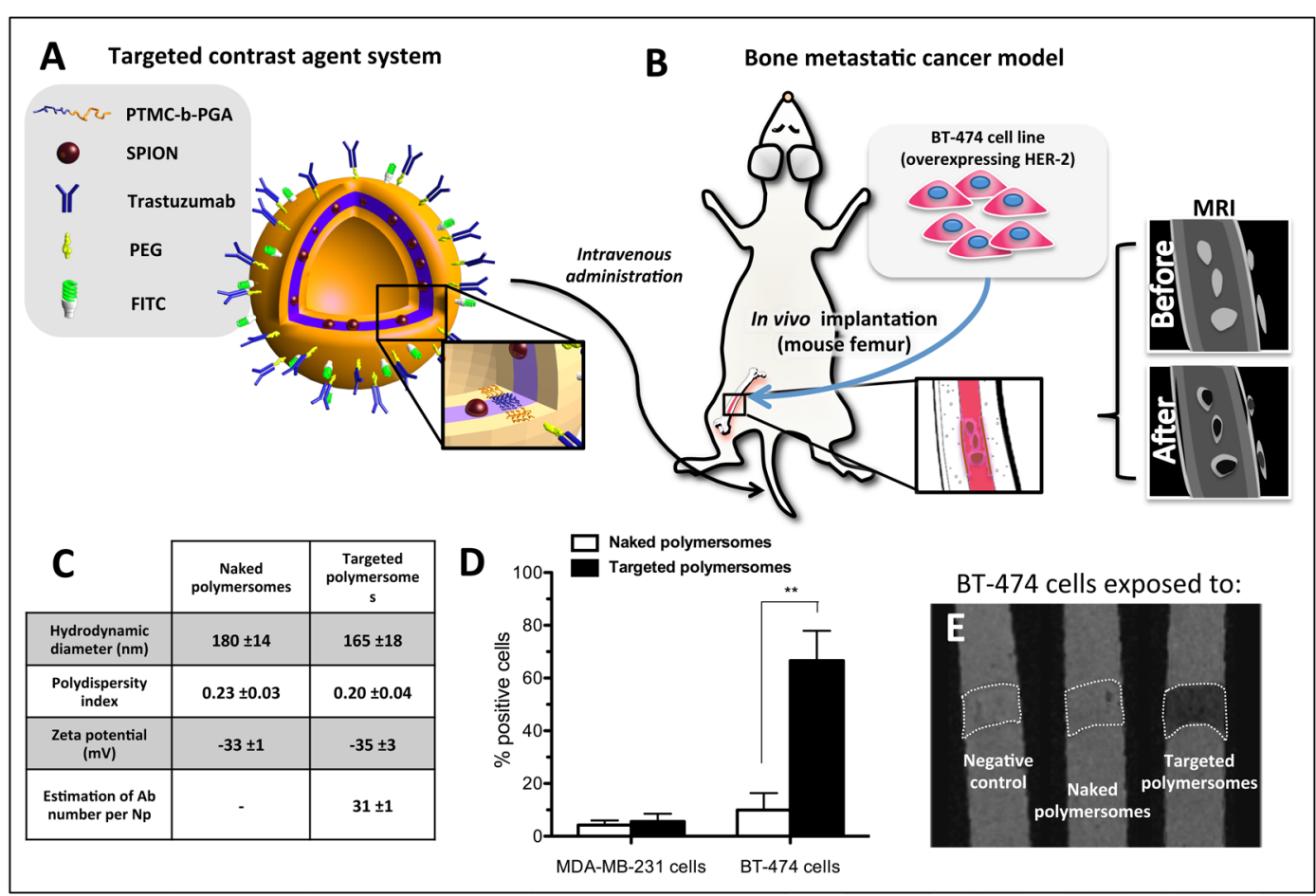


Figure 1 - (A) Multifunctional polymersomes loaded with maghemite nanoparticles and grafted with fluorescein and targeting antibodies, directed against Human Epidermal Growth Factor Receptor-2 (HER2), were developed as novel MRI contrast agents for bone metastasis imaging. (B) Schematic of bone metastasis model and the study's principle: upon administration, in NOD/SCID mice bearing metastatic breast cancer (overexpressing HER2), MR images will show targeting and enhanced retention of antibody-labeled polymersomes at the tumor site. (C) Main properties of targeted and non-targeted hybrid polymersomes. (D) In vitro targeting efficiency of functionalized hybrid vesicles, expressed as $\%$ of fluorescent positive cells after $3.5 \mathrm{~h}$ incubation time of targeted or naked polymersomes in BT-474 (cell line that overexpresses the targeted receptor, HER2) and MDA-MB-231 (cell line expressing low levels of HER2) cells $(* * p=0.0079)$. (E) Targeting was also evaluated by means of MRI: after incubation with polymersomes for $24 \mathrm{~h}$, cells were embedded in a transparent gel and observed by MRI (area containing the cells are delimited by white dashed line). The strong lowering of the signal (negative contrast) observed in the right column confirms the uptake of the iron oxide containing targeted polymersomes. On the contrary, for naked polymersomes, no change in contrast is observed as compared to control cells.

As observed in Figure 1C, naked and antibody-grafted polymersomes presented similar size and zeta potential, consistent with previous reports. ${ }^{[13,23]}$ Using the previously determined aggregation number, ${ }^{[23]}$ we estimated an average number of antibody per vesicle of 31 , corresponding to a grafting efficiency of $86 \%$ (Supporting Information). The developed systems relaxivity $\left(\mathrm{r}_{2}\right)$ was evaluated at $4.7 \mathrm{~T}$ (200 MHz operating frequency) and values were found consistent with previous reports using similar USPIOs. ${ }^{[9,24]}$

The targeting potential of the developed system was first tested in an in vitro setting. After exposure to the polymer vesicles, cells were analyzed by flow cytometry: polymersomes fluorescently labeled and functionalized with trastuzumab showed a clear targeting (six fold increase of the number of FITC positive cells) towards BT-474 cells (HER2 positive) as compared with naked particles (Figure 1D). Moreover, when cells expressing low levels of HER2 (i.e. MDA-MB-231 breast cancer cell line ${ }^{[25]}$ ) were used, no significant differences were observed for the two formulations tested (Figure 1D), demonstrating the specificity of the targeting. Interestingly, thanks to the polymersomes high USPIOs content, MRI also evidenced the targeting towards BT-474 cells. Indeed, as observed in Figure 1E, cells incubated with targeted polymersomes and embedded in a transparent gel appeared with a 
negative contrast $\left(T_{2}{ }^{*}\right.$ effect in gradient echo images), accounting for the uptake of polymersomes, whereas cells incubated with naked polymersomes showed no change in contrast as compared to control cells.

MRI was also used to perform real time whole body biodistribution ${ }^{[26]}$ (4.7 Tesla; Figure 2A). Figure 2B presents signal-to-noise ratio (SNR) as a function of time (pre-contrast minus postcontrast values, $\triangle \mathrm{SNR}$ ) for 3 tissues (i.e. blood, liver and muscle). Despite a quick uptake by the liver, blood data show that the injected polymersomes persist in circulation for at least 20 min (Figure 2A and 2B). Similar results where found after naked polymersomes administration (data not shown) and for other nanoparticles with similar sizes. ${ }^{[27]}$ Interestingly, MRI signal analysis of the tumor tissue showed that naked polymersomes are less retained than the targeted ones (Figure 2E). Additionally, superior contrast was observed in the tumor bone, when compared with the contralateral femur tissue (Figure 2C, D), attesting the targeting specificity in a clinically relevant in vivo scenario.

A
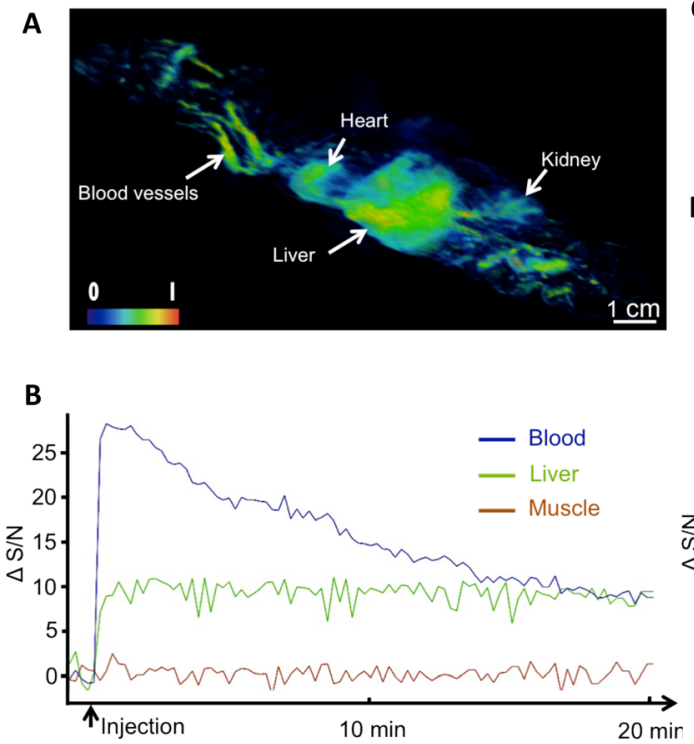

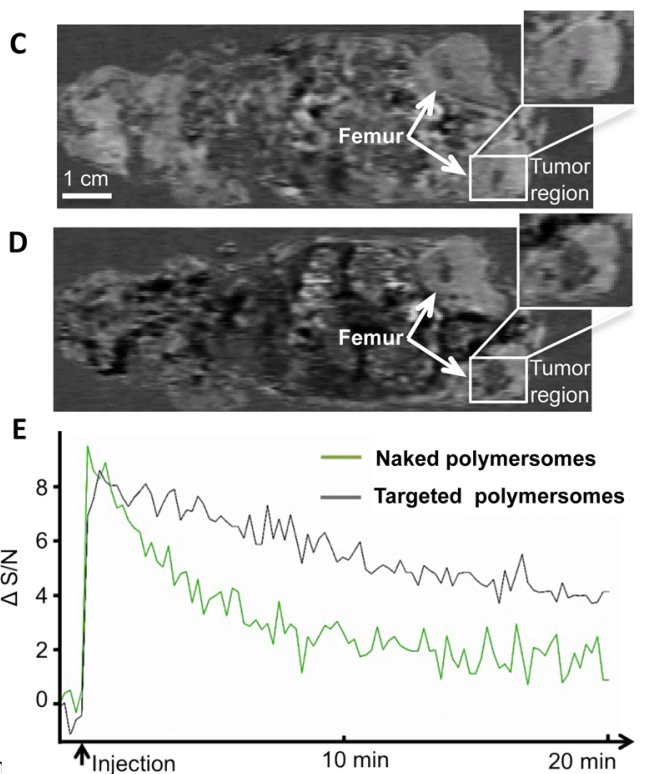

Figure 2 - (A) Biodistribution of $T_{2}{ }^{*}$ targeted polymersome in tumor bearing mice. Normalized 3D volume rendering of contrast agent accumulation throughout time. (B) $\triangle \mathrm{SNR}$, in relevant organs, after targeted polymersome administration and as a function of time (20 min). (C) Pre-contrast whole body MR images before targeted polymersome administration. (D) Pre-contrast minus post-contrast whole body MR images 5 min post polymersome administration. (E) $\triangle \mathrm{SNR}$ in the tumor site after naked or targeted polymersome administration, as a function of time (20 $\mathrm{min})$. 
High resolution MR imaging and three dimension acquisition and analysis was then used to further study the in vivo targeting properties and localization within the bone tumor. First, signal analysis (percent signal change) at the tumor site (bone) permits, using a color code, to reveal the variations in terms of contrast after polymersome administration (Figure 3E, F): the targeted system clearly demonstrated higher contrast as compared to the naked polymersomes. Finer observations (Figure 3A, C) revealed that tumor growth could be observed inside the bone lumen, and, at a later stage, outside the bone. When naked polymersomes were administered, no contrast differences were observed in the tumor area either inside or outside the bone. On the contrary, when targeted polymersomes were used, tumor boundaries became darker (Figure 3B, D), indicating specific targeting of cancer tissue even though the polymersome penetration inside the bone seemed scarce.

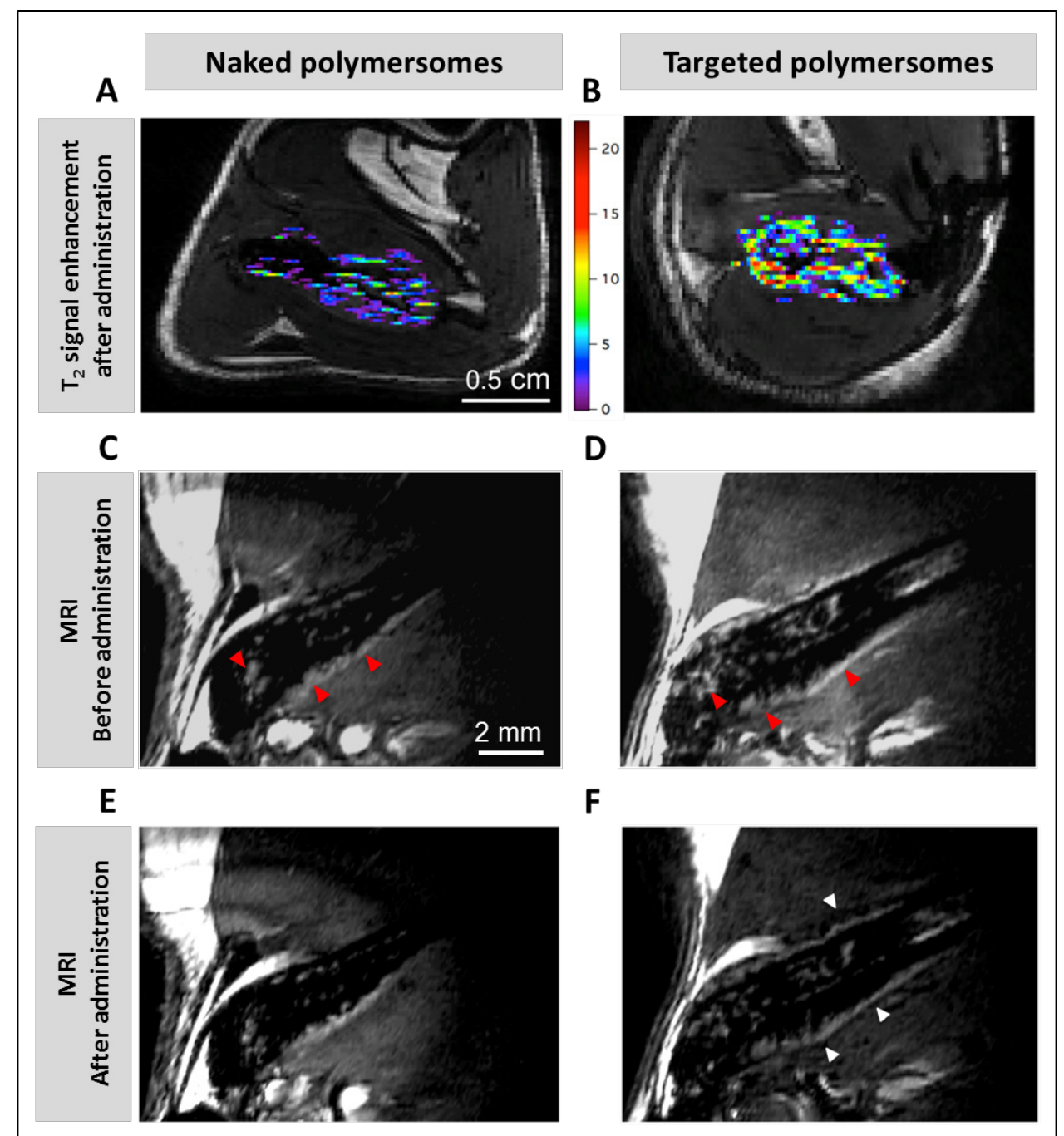

Figure 3 - Extracted longitudinal MRI views of bone in vivo. 3D TrueFISP image before (A, B) and after $(\mathbf{C}, \mathbf{D})$ naked $(\mathrm{n}=4)$ or targeted $(\mathrm{n}=6)$ polymersome administration (respectively) to tumor-bearing mice. Percentage signal change at the tumor site after naked or targeted polymersome injection, $(\mathbf{E})$ and $(\mathbf{F})$ respectively. Experiments were performed when the tumors reached a volume of 12 to $15 \mu \mathrm{l}$. Red arrows on MR images denote tumor tissue. White arrows on MR images denote contrast variations on tumor boundaries. 
This behavior can be explained by the small size of the internal lesions without fully developed vascularization in the bone. Indeed, larger tumors generally contain leaky vasculature associated with insufficient lymph drainage that is correlated with an enhanced permeability and retention (EPR) effect of nanoparticles also referred to as passive targeting. ${ }^{[28]}$ In the case of smaller tumor structures, where angiogenesis might be less influenced by anoxic conditions, this EPR effect is very limited. In such a context, the development of nanoparticles with an "active targeting" (grafting of a specific ligand) is necessary to reach the tumor and maintain a high concentration at the tumor site. As a result, this was only when targeted polymersomes were used that a more persistent $T_{2}{ }^{*}$ contrast effect was observed at the tumor site, associated with an increased residence time of the contrast agent.

To our knowledge, this is the first report of USPIO-loaded polymeric vesicles used as MRI contrast agent and able to target cancer cells in vivo, in a relevant animal model for bone metastasis. This approach opens new avenues for the development of more powerful diagnostic tools developed on the basis of higher specificity. Indeed, to avoid any loss in binding affinity, only a limited number of contrast agent structures can be grafted onto one antibody. For common MRI contrast agents such as gadolinium complexes, the concentration of contrast agent at the targeted site achieved with such labeled antibodies is usually insufficient to generate detectable MRI contrast. ${ }^{[29]}$ In the case of magnetic polymersomes however, the high relaxivity provided by the USPIOs clustering effect associated with the binding of several antibodies per particle potentiate the efficiency as targeted MRI contrast agent.

Thanks to the versatility of the polymersome structure, other - or complex mixtures of targeting moieties can be used in order to assess other tissues or pathological situations, broadening their application as diagnostic tools. Moreover, as previously reported by our 
group, the developed systems are able to load high amounts of drug and USPIOs (i.e. 12\% (w/w) of doxorubicin while also encapsulating 50\% (w/w) of USPIOs). ${ }^{[13,23]}$ In comparison with other reported vesicular systems, where a doxorubicin loading of only $3.3 \%(\mathrm{w} / \mathrm{w})$ was reached, ${ }^{[7]}$ these polymersomes open new perspectives for the development of targeted tools for a dual diagnostic and therapy purpose.

\section{Experimental Section}

A detailed description of experimental procedures can be found in the supporting information.

\section{Supporting Information}

Supporting Information is available online from Wiley InterScience or from the author.

\section{Acknowledgements}

This work was supported by funding from the European Commission under the seventh framework program within the frame of the NanoTher project (Integration of novel NANOparticle based technology for THERapeutics and diagnosis of different types of cancer CP-IP 213631-2). The authors would also like to thanks European Science Foundation P2M program for support and Prof. J. Robert from Institut Bergonié for antibodies.

Received: December 18, 2012

Revised: February 10, 2013

Published online: April 19, 2013

[1] D. M. Parkin, F. Bray, J. Ferlay, P. Pisani, CA: A Cancer Journal for Clinicians 2005, 55,74 .

[2] G. N. Hortobagyi, Semin Oncol 1991, 18, 11. 
[3] a) R. D. Rubens, European journal of cancer (Oxford, England : 1990) 1998, 34, 210; b) A. Jemal, R. Siegel, E. Ward, Y. Hao, J. Xu, T. Murray, M. J. Thun, CA: A Cancer Journal for Clinicians 2008, 58, 71.

[4] a) F. W. Flickinger, S. M. Sanal, Magnetic Resonance Imaging 1994, 12, 829; b) K. Ando, M. Murakami, Y. Kuroda, A. Sano, S. Nishizawa, T. Masada, S. Miyamoto, Y. Kigami, S. Matsumoto, Y. Kojima, Nippon Igaku Hoshasen Gakkai zasshi. Nippon acta radiologica 1993, 53, 155.

[5] Y.-X. Wang, S. Hussain, G. Krestin, European Radiology 2001, 11, 2319.

[6] a) D. Ho, X. Sun, S. Sun, Accounts of Chemical Research 2011, 44, 875; b) Z. R. Stephen, F. M. Kievit, M. Zhang, Materials Today 2011, 14, 330; c) C. Tu, A. Y. Louie, Wiley Interdisciplinary Reviews: Nanomedicine and Nanobiotechnology 2012, 4, 448; d) J. F. Schultz, J. D. Bell, R. M. Goldstein, J. A. Kuhn, T. M. McCarty, Ann Surg Oncol 1999, 6, 691; e) M. G. Harisinghani, J. Barentsz, P. F. Hahn, W. M. Deserno, S. Tabatabaei, C. H. van de Kaa, J. de la Rosette, R. Weissleder, N Engl J Med 2003, 348, 2491.

[7] a) J. Yang, C. H. Lee, H. J. Ko, J. S. Suh, H. G. Yoon, K. Lee, Y. M. Huh, S. Haam, Angew Chem Int Ed Engl 2007, 46, 8836; b) J. H. Lee, Y. M. Huh, Y. W. Jun, J. W. Seo, J. T. Jang, H. T. Song, S. Kim, E. J. Cho, H. G. Yoon, J. S. Suh, J. Cheon, Nat Med 2007, 13, 95; c) D. Artemov, N. Mori, R. Ravi, Z. M. Bhujwalla, Cancer Res 2003, 63, 2723; d) L. Yang, X. H. Peng, Y. A. Wang, X. Wang, Z. Cao, C. Ni, P. Karna, X. Zhang, W. C. Wood, X. Gao, S. Nie, H. Mao, Clin Cancer Res 2009, 15, 4722; e) Z. Medarova, W. Pham, Y. Kim, G. Dai, A. Moore, Int J Cancer 2006, 118, 2796.

[8] B. M. Discher, Y. Y. Won, D. S. Ege, J. C. M. Lee, F. S. Bates, D. E. Discher, D. A. Hammer, Science 1999, 284, 1143.

[9] a) X. Yang, S. Pilla, J. J. Grailer, D. A. Steeber, S. Gong, Y. Chen, G. Chen, J Mater Chem 2009, 19, 5812; b) X. Q. Yang, J. J. Grailer, I. J. Rowland, A. Javadi, S. A. Hurley, D. A. Steeber, S. Q. Gong, Biomaterials 2010, 31, 9065; c) R. J. Hickey, A. S. Haynes, J. M. Kikkawa, S.-J. Park, Journal of the American Chemical Society 2011, 133, 1517.

[10] C. Sanson, O. Diou, J. Thévenot, E. Ibarboure, A. Soum, A. Brûlet, S. Miraux, E. Thiaudière, S. Tan, A. Brisson, V. Dupuis, O. Sandre, S. Lecommandoux, ACS Nano 2011, 5, 1122.

[11] H. De Oliveira, J. Thevenot, S. Lecommandoux, Wiley Interdisciplinary Reviews: Nanomedicine and Nanobiotechnology 2012, 4, 525.

[12] a) J. S. Lee, T. Groothuis, C. Cusan, D. Mink, J. Feijen, Biomaterials 2011, 32, 9144; b) S. Egli, M. G. Nussbaumer, V. Balasubramanian, M. Chami, N. Bruns, C. Palivan, W. Meier, J Am Chem Soc 2011, 133, 4476.

[13] D. Slamon, W. Godolphin, L. Jones, J. Holt, S. Wong, D. Keith, W. Levin, S. Stuart, J. Udove, A. Ullrich, a. et, Science 1989, 244, 707.

[14] a) R. Bardhan, W. Chen, M. Bartels, C. Perez-Torres, M. F. Botero, R. W. McAninch, A. Contreras, R. Schiff, R. G. Pautler, N. J. Halas, A. Joshi, Nano Letters 2010, 10, 4920; b) T. J. Chen, T. H. Cheng, C. Y. Chen, S. C. Hsu, T. L. Cheng, G. C. Liu, Y. M. Wang, J Biol Inorg Chem 2009, 14, 253.

[15] A. Davoli, B. A. Hocevar, T. L. Brown, Cancer Chemother Pharmacol 2010, 65, 611.

[16] H. F. Dvorak, V. M. Weaver, T. D. Tlsty, G. Bergers, J Surg Oncol 2011, 103, 468.

[17] F. M. Kievit, Z. R. Stephen, O. Veiseh, H. Arami, T. Wang, V. P. Lai, J. O. Park, R. G. Ellenbogen, M. L. Disis, M. Zhang, ACS Nano 2012, 6, 2591.

[18] T. J. Rosol, S. H. Tannehill-Gregg, B. E. LeRoy, S. Mandl, C. H. Contag, Cancer 2003, 97, 748 .

[19] C. Sanson, C. Schatz, J.-F. Le Meins, A. Brûlet, A. Soum, S. Lecommandoux, Langmuir 2010, 26, 2751.

[20] R. Meier, T. D. Henning, S. Boddington, S. Tavri, S. Arora, G. Piontek, M. Rudelius, C. Corot, H. E. Daldrup-Link, Radiology 2010, 255, 527. 
[21] G. D. Plowman, J. M. Culouscou, G. S. Whitney, J. M. Green, G. W. Carlton, L. Foy, M. G. Neubauer, M. Shoyab, Proc Natl Acad Sci US A 1993, 90, 1746.

[22] E. Bled, W. B. Hassen, L. Pourtau, P. Mellet, T. Lanz, D. Schüler, P. Voisin, J.-M. Franconi, E. Thiaudière, S. Miraux, Contrast Media \& Molecular Imaging 2011, 6, 275.

[23] a) P. Calvo, B. Gouritin, H. Chacun, D. Desmaële, J. D'Angelo, J.-P. Noel, D. Georgin, E. Fattal, J. Andreux, P. Couvreur, Pharm Res 2001, 18, 1157; b) C. Giraudeau, B. Djemaï, M. A. Ghaly, F. Boumezbeur, S. Mériaux, P. Robert, M. Port, C. Robic, D. L. Bihan, F. Lethimonnier, J. Valette, NMR in Biomedicine 2012, 25, 654.

[24] S. Goel, D. G. Duda, L. Xu, L. L. Munn, Y. Boucher, D. Fukumura, R. K. Jain, Physiol Rev 2011, 91, 1071.

[25] S. Gohr-Rosenthal, H. Schmitt-Willich, W. Ebert, J. Conrad, Investig Radiol 1993, 28. 


\section{Supporting Information for}

\section{Antibody-functionalized magnetic polymersomes: in vivo targeting and}

\section{imaging of bone metastases using high resolution MRI}

By Line Pourtau ${ }^{+}$, Hugo Oliveira ${ }^{+}$, Julie Thevenot, Yali Wan, Alain Brisson, Olivier Sandre, Sylvain Miraux, Eric Thiaudière* and Sébastien Lecommandoux*

\section{$\underline{\text { Experimental Section }}$}

Polymersomes formulation and characterization:

Poly(trimethylene carbonate)- $b$-poly(l-glutamic acid) (PTMC- $b$-PGA) copolymer was synthesized by ring-opening polymerization as previously described ${ }^{[30]}$. In order to form thiol-reactive vesicles, based on PTMC- $b$-PGA copolymer, a triblock formation strategy was followed. In that sense a bifunctional (i.e. N-Hydroxysuccinimide and maleimide) $2 \mathrm{kDa}$ PEG (JenkemUSA, China) was grafted to the diblock copolymer. Briefly, PTMC $26-\mathrm{PGA}_{20}(0.65 \mathrm{~g})$ was dissolved in anhydrous DMSO $(13 \mathrm{~mL})$ in the presence of 1 equivalent of N,Ndiisopropylethylamine (DIPEA) per acid group. Then bifunctional PEG (0.25 g) was dissolved in anhydrous DMSO $(5 \mathrm{~mL})$ and mixed to the previous solution. The reaction continued for $24 \mathrm{hrs}$ in a $\mathrm{N}_{2}$ atmosphere, at room temperature. The solution was concentrated by means of ultrafiltration $(1 \mathrm{kDa})$ to a final volume of $5 \mathrm{~mL}$ and the copolymer precipitated by the addition of cold dichloromethane: diethyl ether $(1: 2)(150 \mathrm{~mL})$. The obtained solid was extensively washed with diethyl ether, vacuum dried overnight and stored at $-20{ }^{\circ} \mathrm{C}$ until further use.

For fluorescent labeling, PTMC- $b$-PGA was modified in bulk using FITC. Briefly, copolymer $(250 \mathrm{mg})$ was dissolved in anhydrous DMSO $(5 \mathrm{~mL})$ and DIPEA $(100 \mu \mathrm{L} ; 1$ eq. per acid function) was added. After 5 min stirring, FITC (18 mg; 1 eq.) was added and the mixture was stirred overnight at room temperature. The resulting product was dialyzed against ultrapure water for three days and freeze dried.

The strategy of the antibody grafting to the polymersome surface consisted in the reaction of the thiolated protein to the active maleimide groups in the polymersome surface. In that sense the antibody was thiolated in a controlled fashion, as follows. Trastuzumab (purified from Herceptin ${ }^{\circledR}$, Roche) was dispersed in $50 \mathrm{mM}$ phosphate buffer $\mathrm{pH} 8.0$ (at $5 \mathrm{mg} / \mathrm{mL}$ ) and a 50 fold molar excess of 2-iminothiolane (Sigma) was added and left to react for $2 \mathrm{hrs}$ at room temperature, as described elsewhere ${ }^{[31]}$. Unreacted 2-iminothiolane was removed using ultrafiltration (50 kDa, Spinx-UF20, Corning) with $50 \mathrm{mM}$ phosphate buffer $\mathrm{pH}$ 6.5. The 
antibody concentration was determined by OD280 (corrected to $1 \mathrm{mg} / \mathrm{mL}$ ), snap frozen and kept at $-20^{\circ} \mathrm{C}$ until further use. The number of thiols per antibody was determined using Ellman's assay ${ }^{[32]}$. The influence of thiolation in the antibody dispersion stability was followed by DLS, with no aggregation being observed (Figure S1, A). Tratuzumab antibody presented a hydrodynamic diameter of $12.3 \pm 1.1$ and $12.9 \pm 0.4 \mathrm{~nm}$, with a polydispersity index of 0.18 and 0.17 , for native and thiolated, respectively.

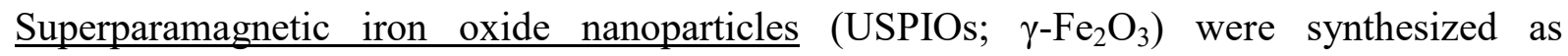
previously described ${ }^{[33]}$, sorted according to their size by fractionated phase separations and characterized along the sorting process by vibrating sample magnetometry (VSM) and on the final sample by scattering techniques (SLS, DLS and SANS). Then they were grafted with the anionic surfactant Beycostat NB09 (CECA, Arkema group, France) as described elsewhere ${ }^{[34]}$, in order to allow their inclusion in the polymersome hydrophobic reservoir.

Polymersomes were obtained by the nanoprecipitation method (solvent assisted dispersion). Briefly, a mixture of diblock:triblock:FITC-grafted-diblock (PTMC-PGA : PTMC-PGAPEG : PTMC-PGA-FITC; 60:20:20) solution (10 mg/mL final, in DMSO) and USPIOs (at $30 \%$ feed weight ratio) was vortexed with phosphate buffer $(50 \mathrm{mM}, \mathrm{pH} 6.5)$ solution. Nanoparticle were purified via ultrafiltration $(3 \mathrm{x})$ using a filter cut off of $100 \mathrm{kDa}$, with phosphate buffer, $50 \mathrm{mM}, \mathrm{pH}$ 6.5. Total mass of the dispersion was determined using gravimetry and total iron content was assessed as described elsewhere ${ }^{[35]}$. The density of reactive maleimide groups was determined by using a competition Ellman's assay. Briefly, the dispersion $(200 \mathrm{uL}$ ) was mixed to a same volume of a $250 \mathrm{uM}$, L-cysteine (Sigma) solution. This mixture was let to react for $1 \mathrm{hr}, 1100 \mathrm{rpm}$, at room temperature. A control was performed using polymersomes based on PTMC- $b$-PGA alone. In a 96 well plate, each sample $(50 \mathrm{uL})$ was pipetted, together with Tris Buffer $(200 \mathrm{uL}, 30 \mathrm{mM}, \mathrm{pH} 8.9)$ and DTNB (20uL, $29.7 \mathrm{mg}$ DTNB in methanol). The absorption of the formed product was measured at $412 \mathrm{~nm}$. The number of maleimide groups was determined by the loss of thiol concentration, against a L-cysteine calibration curve.

In order to produce targeted polymersomes the thiolated trastuzumab was added to the nanoparticle dispersion at $55 \mu \mathrm{g}$ of antibody per $\mathrm{mg}$ of total copolymer and left to react, overnight, at room temperature. Unreacted antibody was removed by means of ultrafiltration (3 $\mathrm{x}$ ) with phosphate buffer, $50 \mathrm{mM}, \mathrm{pH}=7.4$, using a filter cut-off of $25 \mathrm{~nm}$ (Millipore). Antibody content was determined by means of BCA protein assay. The number of grafted antibodies per nanoparticle was estimated by dividing the number of antibody molecules (measured after final step of purification) by the number of polymersomes in dispersion 
(estimated using the previously determined aggregation number ${ }^{[36]}$ ). The grafting efficiency was expressed as the percentage of grafted antibody (quantified after final step of purification by means of the BCA assay) in relation to the total amount initially reacted with polymersomes. In view of comproving the efficient antibody grafting a small amount of the nanoparticle dispersion, before and after the final step of purification, where loaded in a $7 \%$ SDS PAGE gel (lacking reducing agents). Free trastuzumab was run alongside grafted nanoparticles. As observed in figure S1, B, when the antibody is grafted to the nanoparticles it is unable to enter the gel and appears solely in the well of the stacking gel. Before the last step of purification a faint band is observed at the correspondent size of the free thiolated antibody, corresponding to the small fraction of unreacted antibody (Figure S1, B, column 4). Conversely, after the last step of purification (Figure S1, B, column 5) no free antibody can be detected asserting for the purification procedure.

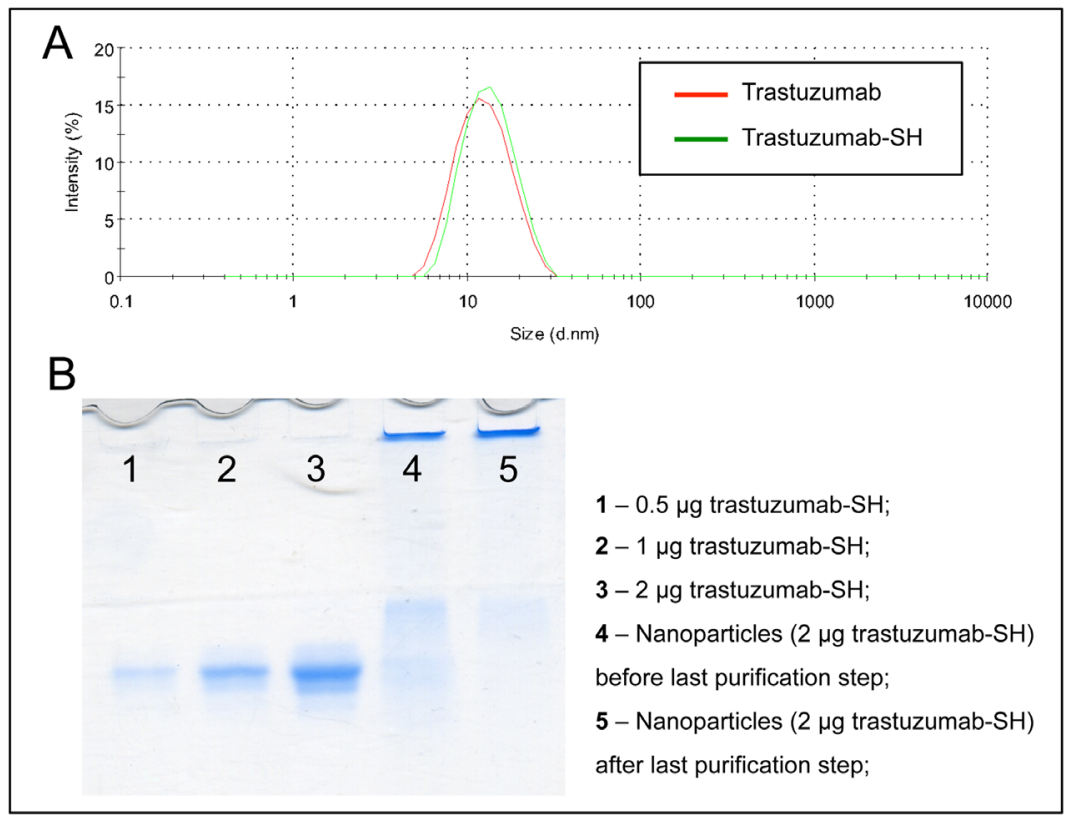

Figure S1- Dynamic light scattering characterization of native and thiolated trastuzumab antibody (trastuzumab and trastuzumab-SH, respectively) (A). Native PAGE 7\% gel of trastuzumab grafted nanoparticles before and after last purification step (B).

Size and zeta potential of the NPs was measured by Dynamic Light Scattering using the NanoZS90 apparatus from Malvern Instrument. Measurement was carried out at $90^{\circ}$. The sample was kept at constant temperature $\left(25^{\circ} \mathrm{C}\right)$ during all the experiment. The Smoluchowski model was applied for zeta potential determination and cumulant analysis was used for mean particle size determination. 
Relaxation rate $R_{2}\left(1 / T_{2}\right)$ measurements of polymersomes were performed as follows. Experiments were carried out at 4.7 T (200 MHz operating frequency) on a Bruker Biospec system (Bruker, Ettlingen, Germany) at $20^{\circ} \mathrm{C}$. T2 measurements were performed at $25^{\circ} \mathrm{C}$ with a CPMG (Carr-Purcell-Meiboon-Gill) imaging sequence (TR, 5000 or 10000 ms; inter echotime: $5 \mathrm{~ms}$; number of echo images: 256; FOV: 50 x $50 \mathrm{~mm}$; matrix: 128 x 128; slice thickness: $2 \mathrm{~mm}$ ).

Cryo-Transmission Electron Microscopy (cryo-TEM). Polymersomes ( $2 \mathrm{mg} / \mathrm{mL}$ in water) were deposited on an EM grid coated with a perforated carbon film. After draining the excess liquid with a filter paper, grids were quickly plunged into liquid ethane cooled down by liquid nitrogen and mounted onto a Gatan 626 cryoholder (Gatan, USA). TEM was performed with a Tecnai F20 microscope (FEI, USA) operated at $200 \mathrm{kV}$. Images were recorded with a $2 \mathrm{k} x$ 2k USC1000-SSCCD camera (Gatan).

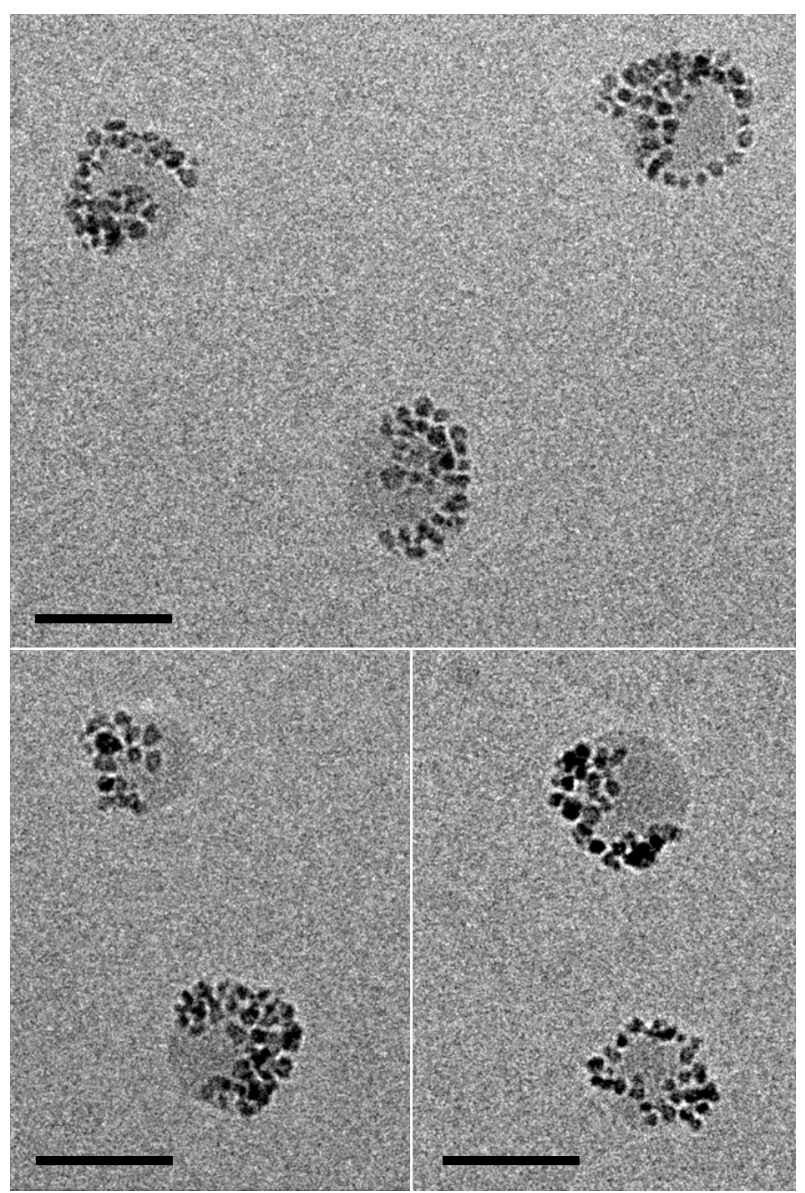

Figure S2 - Gallery of cryo-TEM images showing polymersomes embedded in a thin film of amorphous ice, homogenously distributed and densely coated with magnetic particles.

(scale bar $50 \mathrm{~nm}$ ).

\section{In vitro experiments}

\section{Cell culture:}


Human breast cancer cell lines BT474 and MDA-MB-231 were purchased from the American Type Culture Collection. Tumor cells were cultured routinely in RPMI 1640 and DMEM/F12 (Invitrogen, Carlsblad, CA, USA) respectively, supplemented with $10 \%$ foetal calf serum (Invitrogen, Carlsblad, CA, USA). Cultures were kept under standard conditions $\left(37^{\circ} \mathrm{C}\right.$, humidified atmosphere, $5 \% \mathrm{CO}_{2}$ ) and passaged twice a week to keep them in logarithmic growth.

\section{Cytometry:}

Breast cancer cell lines BT474 and MDA-MB-231 were incubated with NPs (naked or targeted) at $0.2 \mathrm{mg}$ of copolymer per $\mathrm{mL}$ in complete medium and at $37^{\circ} \mathrm{C}$. After $4 \mathrm{hrs}$ incubation with NPs, cells were washed three times with phosphate-buffered saline (PBS), collected and analyzed by flow cytometry Incyte software (Millipore, Billerica, MA, USA).

MRI:

Breast cancer cell lines BT474 and MDA-MB-231 were incubated with NPs (naked or targeted) at $0.2 \mathrm{mg}$ of copolymer per $\mathrm{mL}$ in complete medium and at $37^{\circ} \mathrm{C}$. After $24 \mathrm{hr}$ incubation with NPs, cells were washed three times with phosphate-buffered saline (PBS), collected and trapped in agarose gels $\left(1 \% \mathrm{w} / \mathrm{v}\right.$ in $\left.\mathrm{H}_{2} \mathrm{O}\right)$ for MRI analysis.

A T2*-weighted image was performed at 4.7 Tesla with a FLASH sequence (TE/ TR: 15/40 ms; FOV: 25 x 25 x 25 mm; matrix: 384 x 128 x 128; spatial resolution: 65 x 195 x $195 \mu^{3}$, receiver bandwidth: $6 \mathrm{kHz}$

\section{In vivo experiments}

Bone tumor model:

BT474 breast cancer cells were harvested, counted with a Malassez cell counter and transferred into RPMI medium without serum before injection in NOD/SCID mice (8 week old, body weight $=18-22 \mathrm{~g}$ ). Mice were anesthetized with isoflurane (1-1.5\% in air). After shaving the limb, the femur was exposed and a $0.6 \mathrm{~mm}$ hole was generated with a driller (Harvard Apparatus, Les Ulis, France). Mice were injected with $10 \mu \mathrm{L}$, containing one million tumor cells, into the intramedullary canal of the femur in the epiphysis region with Hamilton syringe. Bone wax was used to obturate the injection hole.

All experimental procedures were approved by the local institutional ethics committee (approval $\mathrm{n}^{\circ} 33010001-\mathrm{A}$ ).

Mice were followed for several months, using MRI, in order to assess tumor progression (Figure S3). Presence of HER2 expression in newly formed tumor tissue in bone was confirmed ex vivo before nanoparticle administration (Figure S4). 
In vivo MRI:

Animal preparation for MRI:

Mice were anesthetized using isoflurane (1-1.5\% in air). Gradient insert temperature was maintained at $37^{\circ} \mathrm{C}$ and a system for monitoring physiological parameters used to control respiration rate (SA Instruments, Inc., Stony Brook, NY, USA).

Biodistribution measurement:

For scanning the whole mouse in one shot, a mouse whole body coil was used. It was an eight-leg high-pass birdcage resonator with a resonator diameter of $28 \mathrm{~mm}$ and a resonator length of $100 \mathrm{~mm}$. The housing allows for a maximum outer diameter of the animal including mouse holder of $25 \mathrm{~mm}$. These dimensions ensure the full coverage of a mouse with a weight up to $25 \mathrm{~g}$.

The resonator was made from flexible printed circuit board with chip capacitors in the endrings for tuning the resonator to the NMR system's frequency of $200.3 \mathrm{MHz}$. Two capacitive coupling schemes including cable traps were used for providing circular polarization during both transmission and reception. Trim capacitors were used for adjusting tune and match when changing loads. A four-pole quadrature hybrid connected the two resonator ports to transmitter and receiver. The resonator shows a Q drop from 300 to 100 when loaded, which indicates that sample losses are dominating.

For the reference image for keyhole reconstruction, two whole-body 3D FISP T2*-weighted images were acquired before and after dynamic contrast enhancement imaging to complete the k-space of dynamic images: TE/TR: 4/8 ms; flip angle: 10; bandwidth: $39 \mathrm{kHz}, \mathrm{FOV}: 95$ x 22 × $22 \mathrm{~mm}$; matrix: 256 × 80 × 64; spatial resolution, $371 \times 275$ × $344(\mu \mathrm{m})^{3}$; number of averages: 8 ; total acquisition time: $5 \mathrm{~min} 3 \mathrm{~s}$.

For dynamic contrast enhancement (DCE), dynamic 3D FISP T2*-weighted was performed with the following parameters: TE/TR: 4/8 ms; flip angle: $10^{\circ}$; bandwidth: $39 \mathrm{kHz}$; FOV: 95 x 22 x $22 \mathrm{~mm}$; matrix: 256 x 44 x 40; spatial resolution, 371 × 500 x $550(\mu \mathrm{m})^{3}$; number of averages, 1; temporal resolution: 14 s/image; number of dynamic images: 96; experimental time, $23 \mathrm{~min}$. A bolus of $100 \mu \mathrm{L}$ of NPs at a dose of $15 \mathrm{mg}$ of copolymer per mL was injected in the tail vein $1 \mathrm{~min}$ after the beginning of the contrast-enhanced imaging experiment.

Keyhole reconstruction and image analysis were performed with homemade software developed on Igor Pro ${ }^{[37]}$.

MRI tumor progression monitoring:

MRI was performed in a vertical bore spectrometer at 9.4 Tesla (Bruker, Ettingen, Germany) without contrast agent injection. The RF coil was a dedicated 8-mm diameter surface probe 
tuned at $400 \mathrm{MHz}$ (Doty, Columbia, SC, USA). The 3D TrueFISP sequence parameters were: TE/TR: 3.48/6.96 ms; FOV: 20 x 16 x $16 \mathrm{~mm}^{3}$; matrix: 256 × 192 x 192; spatial resolution: 78 x $83 \times 83 \mu \mathrm{m}^{3}$, receiver bandwidth: $52 \mathrm{kHz}$. The final 3D TrueFISP image was made from the combination of eight acquisitions sets. Each set was acquired with a specific difference in phase between consecutive radio frequency pulses. The differences in phase were $\Delta \Phi=180^{\circ}$, $0^{\circ}, 90^{\circ}, 270^{\circ}, 45^{\circ}, 135^{\circ}, 225^{\circ}, 315^{\circ}{ }^{[38]}$. Reconstructions were performed with Igor Pro data processing software (Wavemetrics, Lake Oswego, OR, USA). The final TrueFISP images were calculated as the square root of the sum-of-the-square of the eight images. The total acquisition time was 34 minutes.

Tumor volume quantification:

Tumor volume analysis was performed with a semi-automatic segmentation procedure on Amira software (Visage Imaging GmbH, Berlin, Germany). First a volume that encompassed femur was preselected in the MR image. Inside this preselected volume, minimal value of tumor signal was defined by thresholding the signal intensity at 4 times the bone marrow value.

Ex vivo HER2 immunohistochemistry:

Excised bone were decalcified 4 days in ethylene diamine tetraacetic acid 0.5M (SigmaAldrich, St. Louis, MO, USA), dehydrated, embedded in paraffin and sectioned with a Jung model K microtome (Carl Zeiss, Heidelberg, Germany). Ten-micrometer thick sections were used for HER2 immunochemistry. HER2 immunohistochemical detection was performed on slides using an indirect streptavidin-biotin-peroxidase approach (Histostain-SP kit, Invitrogen, Carlsbad, CA, USA). The primary antibody mouse anti HER2/Neu (9G6): sc-08 (Santa Cruz biotechnology, Santa Cruz, CA, USA) was diluted 1:200 in PBS and added for $2 \mathrm{~h}$ at room temperature. After several rinses in PBS, cells were incubated with biotinylated secondary antibody for $10 \mathrm{~min}$ and streptavidin-peroxidase conjugate for $10 \mathrm{~min}$ with intermittent washes in PBS. Slides were stained using 3-amino-9-ethylcarbazole as chromogen in the presence of hydrogen peroxide. Bone sections were mounted and examined by optical microscopy (Zeiss, Le Pecq, France). 


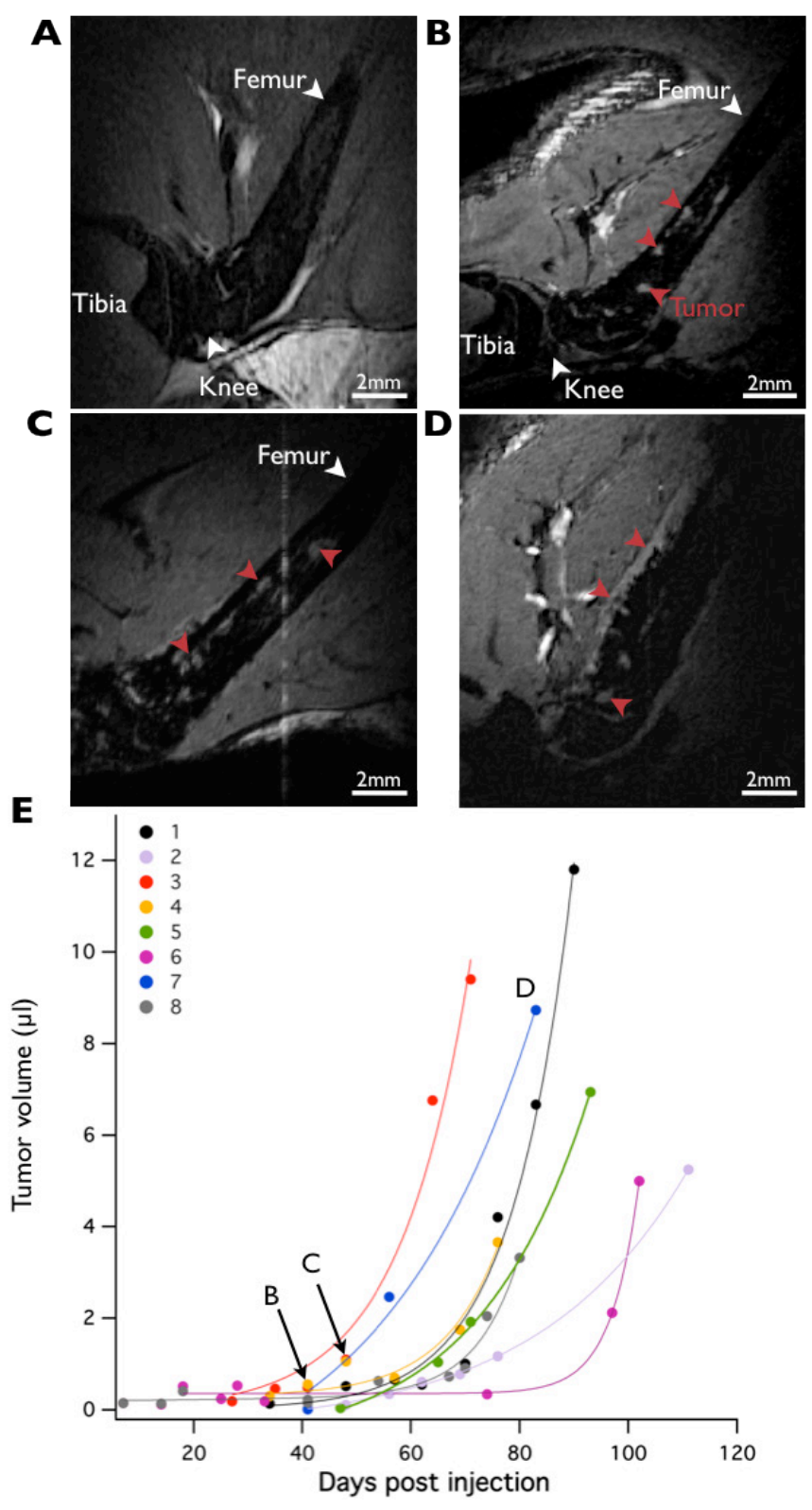

Figure S3-In vivo 3D TrueFISP MRI of the femoral bone of tumor-bearing mice 14 days $(\boldsymbol{A})$, 41 days (B), 48 days $(\boldsymbol{C})$, and 83 days after tumor cells injection (D). Red arrows on MR images show tumor locations. Tumor volume $(\mu l)$ as a function of the elapsed time following BT474 cells implantation (E). Curves fit to a model of exponential growth and are shown for clarity. Letters $(\boldsymbol{B}, \boldsymbol{C}, \boldsymbol{D})$ correspond to the displayed MR images. 


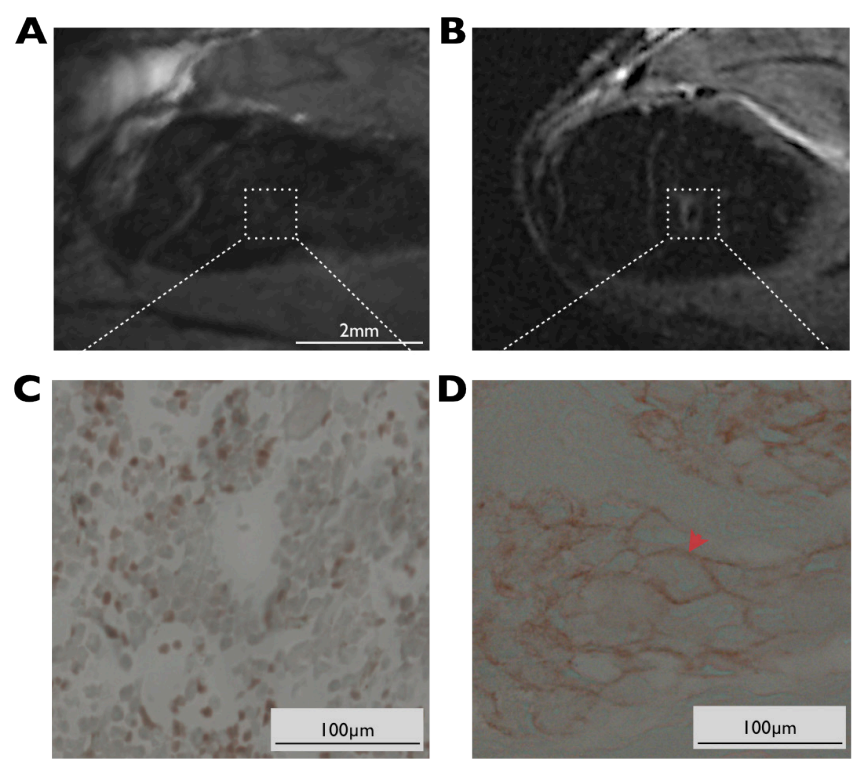

Figure S4- MRI and HER2 immunohistochemistry of an healthy bone mouse $(\boldsymbol{A}, \boldsymbol{C})$ and bone of tumor bearing mouse 87 days post-surgery $(\boldsymbol{B}, \boldsymbol{D})$. $(\boldsymbol{A}, \boldsymbol{B})$ Extracted slice from $3 D$ TrueFISP MRI data. (C,D) Her2 immunochemistry of the corresponding region where presence of HER2 on tumor cells membranes is revealed in red (D).

\section{High resolution imaging of bone tumor targeting}

MRI was performed at 7 Tesla (Bruker, Ettingen, Germany). The RF coil was a dedicated 10$\mathrm{mm}$ diameter surface probe tuned at $300 \mathrm{MHz}$ (Doty, Columbia, SC, USA). The 3D TrueFISP sequence parameters were: TE/TR: 3.2/6.4 ms; FOV: 20 x 15 x 12.5 mm; matrix: 256 x 150 x 128; spatial resolution: $78 \times 100 \times 98 \mathrm{~m}^{3}$, receiver bandwidth: $55 \mathrm{kHz}$. The final 3D TrueFISP image was made of the combination of four acquisitions sets. Each set was acquired with a specific difference in phase between consecutive radio frequency pulses. The differences in phase were $\Delta \Phi=180^{\circ}, 0^{\circ}, 90^{\circ}, 270^{\circ}{ }^{[38]}$. Reconstructions were performed with Igor Pro data processing software (Wavemetrics, Lake Oswego, OR, USA). The final TrueFISP images were calculated as the square root of the sum-of-square of the four images. The total acquisition time was 20 minutes.

A reference image was acquired with these parameters before nanoparticle intra venous bolus injection $(100 \mu \mathrm{L})$. 
[1] D. M. Parkin, F. Bray, J. Ferlay, P. Pisani, CA: A Cancer Journal for Clinicians 2005, 55,74 .

[2] G. N. Hortobagyi, Semin Oncol 1991, 18, 11.

[3] R. D. Rubens, European journal of cancer (Oxford, England : 1990) 1998, 34, 210; A. Jemal, R. Siegel, E. Ward, Y. Hao, J. Xu, T. Murray, M. J. Thun, CA: A Cancer Journal for Clinicians 2008, 58, 71 .

[4] F. W. Flickinger, S. M. Sanal, Magnetic Resonance Imaging 1994, 12, 829; K. Ando, M. Murakami, Y. Kuroda, A. Sano, S. Nishizawa, T. Masada, S. Miyamoto, Y. Kigami, S. Matsumoto, Y. Kojima, Nippon Igaku Hoshasen Gakkai zasshi. Nippon acta radiologica 1993, $53,155$.

[5] Y.-X. Wang, S. Hussain, G. Krestin, European Radiology 2001, 11, 2319.

[6] D. Ho, X. Sun, S. Sun, Accounts of Chemical Research 2011, 44, 875; Z. R. Stephen, F. M. Kievit, M. Zhang, Materials Today 2011, 14, 330; C. Tu, A. Y. Louie, Wiley Interdisciplinary Reviews: Nanomedicine and Nanobiotechnology 2012, 4, 448; J. F. Schultz, J. D. Bell, R. M. Goldstein, J. A. Kuhn, T. M. McCarty, Ann Surg Oncol 1999, 6, 691; M. G. Harisinghani, J. Barentsz, P. F. Hahn, W. M. Deserno, S. Tabatabaei, C. H. van de Kaa, J. de la Rosette, R. Weissleder, N Engl J Med 2003, 348, 2491.

[7] J. Yang, C. H. Lee, H. J. Ko, J. S. Suh, H. G. Yoon, K. Lee, Y. M. Huh, S. Haam, Angew Chem Int Ed Engl 2007, 46, 8836.

[8] J. H. Lee, Y. M. Huh, Y. W. Jun, J. W. Seo, J. T. Jang, H. T. Song, S. Kim, E. J. Cho, H. G. Yoon, J. S. Suh, J. Cheon, Nat Med 2007, 13, 95; D. Artemov, N. Mori, R. Ravi, Z. M. Bhujwalla, Cancer Res 2003, 63, 2723.

[9] L. Yang, X. H. Peng, Y. A. Wang, X. Wang, Z. Cao, C. Ni, P. Karna, X. Zhang, W. C. Wood, X. Gao, S. Nie, H. Mao, Clin Cancer Res 2009, 15, 4722.

[10] Z. Medarova, W. Pham, Y. Kim, G. Dai, A. Moore, Int J Cancer 2006, 118, 2796.

[11] B. M. Discher, Y. Y. Won, D. S. Ege, J. C. M. Lee, F. S. Bates, D. E. Discher, D. A. Hammer, Science 1999, 284, 1143.

[12] X. Yang, S. Pilla, J. J. Grailer, D. A. Steeber, S. Gong, Y. Chen, G. Chen, J Mater Chem 2009, 19, 5812; X. Q. Yang, J. J. Grailer, I. J. Rowland, A. Javadi, S. A. Hurley, D. A. Steeber, S. Q. Gong, Biomaterials 2010, 31, 9065; R. J. Hickey, A. S. Haynes, J. M. Kikkawa, S.-J. Park, Journal of the American Chemical Society 2011, 133, 1517.

[13] C. Sanson, O. Diou, J. Thévenot, E. Ibarboure, A. Soum, A. Brûlet, S. Miraux, E. Thiaudière, S. Tan, A. Brisson, V. Dupuis, O. Sandre, S. Lecommandoux, ACS Nano 2011, 5, 1122.

[14] H. De Oliveira, J. Thevenot, S. Lecommandoux, Wiley Interdisciplinary Reviews: Nanomedicine and Nanobiotechnology 2012, 4, 525.

[15] J. S. Lee, T. Groothuis, C. Cusan, D. Mink, J. Feijen, Biomaterials 2011, 32, 9144; S. Egli, M. G. Nussbaumer, V. Balasubramanian, M. Chami, N. Bruns, C. Palivan, W. Meier, J Am Chem Soc 2011, 133, 4476.

[16] D. Slamon, W. Godolphin, L. Jones, J. Holt, S. Wong, D. Keith, W. Levin, S. Stuart, J. Udove, A. Ullrich, a. et, Science 1989, 244, 707.

[17] R. Bardhan, W. Chen, M. Bartels, C. Perez-Torres, M. F. Botero, R. W. McAninch, A. Contreras, R. Schiff, R. G. Pautler, N. J. Halas, A. Joshi, Nano Letters 2010, 10, 4920.

[18] T. J. Chen, T. H. Cheng, C. Y. Chen, S. C. Hsu, T. L. Cheng, G. C. Liu, Y. M. Wang, J Biol Inorg Chem 2009, 14, 253.

[19] A. Davoli, B. A. Hocevar, T. L. Brown, Cancer Chemother Pharmacol 2010, 65, 611.

[20] H. F. Dvorak, V. M. Weaver, T. D. Tlsty, G. Bergers, J Surg Oncol 2011, 103, 468.

[21] F. M. Kievit, Z. R. Stephen, O. Veiseh, H. Arami, T. Wang, V. P. Lai, J. O. Park, R. G. Ellenbogen, M. L. Disis, M. Zhang, ACS Nano 2012, 6, 2591.

[22] T. J. Rosol, S. H. Tannehill-Gregg, B. E. LeRoy, S. Mandl, C. H. Contag, Cancer 2003, 97, 748 . 
[23] C. Sanson, C. Schatz, J.-F. Le Meins, A. Brûlet, A. Soum, S. Lecommandoux, Langmuir 2010, 26, 2751.

[24] R. Meier, T. D. Henning, S. Boddington, S. Tavri, S. Arora, G. Piontek, M. Rudelius, C. Corot, H. E. Daldrup-Link, Radiology 2010, 255, 527.

[25] G. D. Plowman, J. M. Culouscou, G. S. Whitney, J. M. Green, G. W. Carlton, L. Foy, M. G. Neubauer, M. Shoyab, Proc Natl Acad Sci U S A 1993, 90, 1746.

[26] E. Bled, W. B. Hassen, L. Pourtau, P. Mellet, T. Lanz, D. Schüler, P. Voisin, J.-M. Franconi, E. Thiaudière, S. Miraux, Contrast Media \& Molecular Imaging 2011, 6, 275.

[27] P. Calvo, B. Gouritin, H. Chacun, D. Desmaële, J. D'Angelo, J.-P. Noel, D. Georgin, E. Fattal, J. Andreux, P. Couvreur, Pharm Res 2001, 18, 1157; C. Giraudeau, B. Djemaï, M. A. Ghaly, F. Boumezbeur, S. Mériaux, P. Robert, M. Port, C. Robic, D. L. Bihan, F. Lethimonnier, J. Valette, NMR in Biomedicine 2012, 25, 654.

[28] S. Goel, D. G. Duda, L. Xu, L. L. Munn, Y. Boucher, D. Fukumura, R. K. Jain, Physiol Rev 2011, 91, 1071.

[29] S. Gohr-Rosenthal, H. Schmitt-Willich, W. Ebert, J. Conrad, Investig Radiol 1993, 28.

[30] M. Le Hellaye, N. Fortin, J. Guilloteau, A. Soum, S. Lecommandoux, S. M. Guillaume, Biomacromolecules 2008, 9, 1924.

[31] I. Steinhauser, B. Spankuch, K. Strebhardt, K. Langer, Biomaterials 2006, 27, 4975.

[32] G. L. Ellman, Arch Biochem Biophys 1959, 82, 70.

[33] R. Massart, E. Dubois, V. Cabuil, E. Hasmonay, J. Magn. Magn. Mater. 1995, 149, 1.

[34] C. Da Cruz, O. Sandre, V. Cabuil, J Phys Chem B 2005, 109, 14292.

[35] A. M. Rad, B. Janic, A. S. Iskander, H. Soltanian-Zadeh, A. S. Arbab, Biotechniques 2007, 43, 627.

[36] C. Sanson, C. Schatz, J.-F. o. Le Meins, A. Brûlet, A. Soum, S. b. Lecommandoux, Langmuir 2010, 26, 2751.

[37] E. Bled, W. B. Hassen, L. Pourtau, P. Mellet, T. Lanz, D. Schuler, P. Voisin, J. M. Franconi, E. Thiaudiere, S. Miraux, Contrast Media Mol Imaging 2011, 6, 275.

[38] S. Miraux, P. Massot, E. J. Ribot, J. M. Franconi, E. Thiaudiere, J Magn Reson Imaging 2008, 28, 497. 